\title{
MITOLOGIA DO CRIME / MYTHOLOGY OF CRIME
}

Vinício Carrilho Martinez: Professor Adjunto II da Universidade Federal de Rondônia, junto ao Departamento de Ciências Jurídicas. Doutor pela Universidade de São Paulo.

Fátima Ferreira P. dos Santos: Professora de Ética e Noções de Direito no Centro Universitário/UNIVEM/Marilia-SP. Mestre em Direito.

Toda a moral se configurou sempre pelo modelo do imoral.

Adorno

RESUMO: O texto procura retratar o surgimento de uma espécie de mito da criminalidade, a partir dos anos 1990, sobretudo em São Paulo. Não se trata de uma análise histórica de associações criminosas que surgiram nos entremeios da incapacidade pública em gerir o Estado de Direito. Em todo caso, as nuances de realidade indicadas no texto são suficientes para que se anteponha esta forma de irracionalidade social diante do formalismo jurídico.

PALAVRAS-CHAVE: mito da criminalidade; Estado de Direito; ressocialização.

\begin{abstract}
The text aims to portray the emergence of the criminality myth since 90s, especially in São Paulo. This is not an historical analysis of the criminal associations that emerge from the difficulties on manage the Rule of Law. By all odds, the nuances of reality pointed in the text are adequate to put in different sides the social irrationality and the juridical formalism.
\end{abstract}

KEY-WORDS: Criminality myth, Rule of Law, Re-socialization.

\section{I - Socializados pela política criminosa}

Por ocasião de grandes ou importantes modificações na base legal, a exemplo do Código Penal, retomam-se os debates sobre o significado do direito, da lei. No exemplo do Código Penal sempre cabe a reflexão sobre a finalidade da pena. Os clássicos nos ensinaram, nos primeiros anos do curso de direito, que a principal finalidade da pena é a humanização do sujeito em desacordo com a lei. Vemos especialistas ou curiosos afirmarem que a ressocialização de presos é mito, fantasia, coisa de Papai Noel. Ressocializar criminalmente implica em dizer que a pessoa habituada pelo crime, dominadora dos valores, regras e práticas criminosas, seria capaz de, uma vez presa, mudar de atitude, modificar-se por completo a ponto de adquirir ou respeitar os valores e hábitos socialmente recomendados. 


\section{Quaestio Iuris}

Para alguns seria como trocar de religião, sendo-se praticante e crente das mitologias seguidas não haveria como mudar de lado; note-se que, na base da cultura brasileira, é possível visualizar o sincretismo religioso como troca ou mescla de elementos de várias religiões, sem a presença - até recentemente - dos elementos do fundamentalismo religioso. Porém, em outros, compara-se, está certo que não funcionaria ou seria muito difícil porque equivaleria a confrontar o fanatismo e o fundamentalismo religioso, o tribalismo, ou mudar o time do coração. A ressocialização exigiria mudar de lado, estando-se em guerra, sendo valente combatente a serviço de seu país e daí mudar de lado; mas, sem ser mercenário. É possível um nazista virar um religioso? Isto é, seria necessária a mudança profunda, uma guinada, uma real metamorfose. Nessa linha, pode-se perguntar: quantos mafiosos arrependidos - não importa a razão - passaram a colaborar com o Estado?

Alguns alegam que nada disso será possível porque o sujeito não quer abandonar a vida que sempre levou. Outros, talvez até bem intencionados, dizem que, se até o findar da infância não se formou no indivíduo a credibilidade nos valores sociais e morais rotineiros, então, a chance está perdida e nada pode ser feito. Os funcionalistas têm uma base científica, mas estão presos a um funcionalismo exacerbado. Também chamado de "socialização primária", este processo de impregnação moral tem uma faixa, uma fase, um determinado momento em que, mais ou menos, será definido o que seremos pelo resto da vida. A maturidade emocional, moral tem de ser marcada nesta transição da criança para a adolescência porque seria como delimitar, demarcar as bases da estrutura, condição moral, psíquica. Segundo o filósofo inglês John Locke, o homem é uma "tábula rasa" até que se preencha - e isto seria feito nesta faixa etária, agora estando de acordo com o sociólogo francês Émile Durkheim.

Como diz o filósofo italiano Umberto Eco, no livro Cinco Escritos Morais, somente se educa um cidadão para a tolerância quando se respeita o Outro - diferente e divergente. Do contrário, sendo incapazes de passar para o lado de lá, significa que ficamos por aqui sem nos ver, ou seja, também não nos respeitamos. Por isso, deveríamos educar "quem" ainda pode ser educado: "Educar para a tolerância adultos que atiram uns nos outros por motivos étnicos e religiosos é tempo perdido. Tarde demais. A intolerância selvagem deve ser, portanto, combatida em suas raízes, através de uma educação constante que tenha início na mais tenra infância, antes que possa ser escrita em um livro, e antes que se torne uma casca comportamental espessa e dura demais".

Não se educa o fundamentalista porque não se quer mexer nos dogmas, nas estruturas psicossociais, morais que formam a estrutura cultural do indivíduo. É o equivalente de se dizer que 
sem aquela estruturação não haveria vida social possível. Neste sentido, também pode-se dizer que há um fundamentalismo jurídico. Mas ainda há um fundacionalismo - entenda-se como a tentativa de se buscar no conhecimento certos fundamentos últimos. De tal modo que o próprio conhecimento derivaria desses fundamentos. Admitem-se proposições absolutas, indiscutíveis e evidentes por si mesmas. Portanto, todo reducionismo é fundamentalista.

Por sua vez, o Fundamentalismo procura pelas fundações e exatamente pelos fundamentos (pois esta atitude exigiria o exame, a análise criteriosa), quando se segue literalmente determinados ensinamentos: fundamentalismo religioso ou jurídico. Fundamento ainda pode equivaler, dependendo do emprego, a princípios, à razão de..., à origem. A origem que guarda os segredos, os mistérios e que dão sentido a todo o resto, porque tudo guarda dependência de significados com relação a sua origem. A saída dos fundamentos, da base cognitiva e moral que conforma a sociedade capitalista, como valores judaico-cristãos, é que geraria esta série de subterfúgios, desinteligências, antinomias, entropias e anomias sociais.

\section{II - Do positivismo moral à positivação legal}

Vemos que a ideia de que a anomia ( $\mathrm{a}=$ não; a nomos = sem normas) é uma forma avançada de desagregação social, fomentadora da violência social e, em contrapartida do Estado, e resulta da falta de prudência institucional, como prevenção dos conflitos. Neste modelo, o indivíduo mal ressocializado, a partir da precária socialização primária, seria absolutamente incapaz de adquirir novo código de valores e de condutas. Assim, a anomia social indica expressamente ausência, falta, privação, inexistência de observação e cumprimento de normas, regras, leis. No fundo, é como se dissesse que a socialização necessita tanto do direito quanto da educação a fim de se obter melhores resultados do próprio "processo civilizatório".

Durkheim ainda afirmava que, na Alemanha, burguês e citadino eram sinônimos, e que o direito urbano era o direito do lucro. Os termos forenses ou mercatores designavam sem distinção os habitantes das cidades: o jus civile ou direito urbano ("evolutivamente" contratual, retraindo-se o penal) era sinônimo de jus fori ou direito do mercado. Direito e economia se unificaram nas estruturas sociais herdadas da divisão social do trabalho. No século XX, o direito público passou a envolver e a redimensionar o próprio poder, numa aliança entre "democracia representativa" e Estado de Direito. Durkheim também inventariou algumas das criações mais lógicas da modernidade, para em seguida confrontá-las com suas formas contraditórias: 


\begin{abstract}
Quanto à civilização, ela tem uma influência complexa sobre essa tendência. Aprimoramento dos meios de transporte e de comunicação certamente contribuíram para a aceleração desse movimento de concentração; avanços tecnológicos aliviaram o peso esmagador do trabalho mecânico sobre o desenvolvimento da mente; a educação se distribuiu entre classes que a ela não tinham acesso, e o Estado passou a exigi-la de seus cidadãos [...] Finalmente, a atual organização da indústria tem o efeito de separar os empresários mais e mais dos trabalhadores, revivendo a escravidão, que assume uma nova forma (Durkheim, 2003, p. 75).
\end{abstract}

A divisão do trabalho, portanto, deve buscar o complemento e o crescimento mútuo, e não a oposição e a contrariedade: "Por mais ricamente dotados que sejamos, sempre nos falta alguma coisa, e os melhores dentre nós têm o sentimento de sua insuficiência [...] É essa partilha de funções, ou, para empregarmos a expressão consagrada, essa divisão do trabalho que determina essas relações de amizade" (Durkheim, 1999, pp. 18-21).

Como complemento, o direito constituído (Jus constitutum) é o direito da autoridade (pode ser o pai ou o professor), do governo, de que tem o poder (Jus empirii), e funciona como reflexo da arte do bom e do justo (Jus est ars boni et aequi). Por esta vertente funcionalsistêmica, equilíbrio e harmonia estão na não-dissensão, coibindo-se a anomia (= sem normas), como atentado contra o direito posto. É evidente como se fundem direito e capital. Então, este "funcionalismo" requer certa "harmonia social", e que também emerge da "solidariedade orgânica": o tipo essencial das modernas sociedades capitalistas - alicerçadas mais no "contrato" e no direito civil ou direito contratual, do que no âmbito penal. Basicamente, porque o direito contratual se aplica ao comércio, à indústria, à ciência e tecnologia (direitos autorais, por exemplo) e subsequentemente ao Estado.

O que certamente lembra e ação exercida pela "exterioridade" e "coerção" dos fatos sociais. A diferença é que, ao invés de uma simples acomodação com as normas e regras estabelecidas, o choque, a entropia (ou anomia) do novo, com o já determinado é iminente - "este desarranjo do jovem com o já posto levaria a mudanças" (ou à sua requisição). Neste curso, a síntese ideológica se verifica em um pensamento simples: "É preciso conhecer bem a máquina, para azeitar o seu funcionamento". Este "azeite social" fará do positivismo de Comte e de Durkheim, o meio de seu desembarque na racionalidade industrial. A crença estaria depositada na equação de que industrialismo e racionalismo seriam capazes ou suficientes para inibir as anomias sociais - veja-se que se fala de anomia e não de antinomia. No entanto, é desse modo que Durkheim irá se integrar ao Estado Moderno, especialmente porque a racionalidade se aplica tanto à cotidianidade quanto à política institucional. 
A adesão à moralidade capitalista (e mais ampla, como cultura judaico-cristã) seria algo mais do que natural, seria a realização inexorável da evolução da espécie e da cultura civilizatória que nos orienta. Neste circuito não há volta possível, em razão do que nos impulsiona à autoconservação. Afinal: "Isto não é razão para fazer retroceder a humanidade - proposta tão ridícula quanto absurda -, pois o mundo avança inexoravelmente e é impossível evitar a mudança" (Durkheim, 2003, p. 75).

\title{
III - O Direito e a solidariedade contratual
}

Neste sentido, o crime será visto como anomia (anomalia em virtude da razão), que desafia a solidariedade e assim deveriam ser punidos. Os crimes econômicos, entretanto, desafiam muito mais a estabilidade social e nem sempre tem penas correspondentes:

\begin{abstract}
Embora o ato criminoso seja certamente prejudicial à sociedade, nem por isso o grau de nocividade que ele apresenta é regularmente proporcional à intensidade da repressão que recebe. No direito penal dos povos mais civilizados, o assassinato é universalmente considerado o maior dos crimes. No entanto, uma crise econômica, uma jogada na Bolsa, até mesmo uma falência podem desorganizar o corpo social de maneira muito mais grave do que um homicídio isolado. Sem dúvida, o assassinato é sempre um mal, mas nada prova que seja o mal maior. O que é um homem a menos na sociedade?

(Durkheim, 1999, pp. 41-42).
\end{abstract}

No Brasil, o crime mais fortemente apenado é o latrocínio: homicídio que encobre o objeto do roubo. É também interessante notar como a aplicação da pena segue o curso da divisão do trabalho: mandantes, partícipes (co-autores) e executores: o soldado do crime numa das pontas e o cabeça, normalmente de colarinho branco, na outra. Entre os próprios presos, o crime de estelionato é bastante agraciado, porque envolve planejamento, inteligência, método, racionalidade - é o típico crime da modernidade. Ironicamente, as penas contra a "ordem econômica popular" são brandas (contrariando até mesmo Durkheim).

De modo geral, no entanto, as penas na sociedade moderna são menos aparentes: "Em primeiro lugar, a pena consiste numa reação passional. Essa característica é tanto mais aparente quanto menos cultas são as sociedades" (Durkheim, 1999, pp. 56-57). Exemplo disso é a transformação da pena de prisão em prestação de serviços à comunidade, quando o delito não é tão grave. Por isso, a sociedade moderna deveria manter organizadamente a consciência coletiva: “Todo estado forte da consciência é uma fonte de vida, é um fator essencial de nossa vitalidade geral. Por conseguinte, tudo o que tende a enfraquecê-lo nos diminui e nos deprime; resulta daí 


\section{Quaestio Iuris}

uma impressão de confusão e de mal-estar análoga à que sentimos quando uma função importante é suspensa ou retardada (Durkheim, 1999, p. 68).

Para muitos, a consciência ainda inibe a ação, pois a função da pena para Durkheim não é punitiva, nem reparadora - sua função é manter a coesão social, a consciência coletiva. Seguindo a distinção do direito, Durkheim irá alinhavar as regras gerais do contrato moderno.

Ainda é interessante notar que a aptidão profissional ou, de maneira geral, "aptidão para o trabalho", também obedece à predisposição genética. Seria uma forma de medir as capacidades: "O indivíduo recebe, ao nascer, gostos e aptidões que o predispõem mais a certas funções que a outras, e essas predisposições têm certamente influência sobre a maneira como as tarefas se repartem" (Durkheim, 1999, p. 309). É o que também poderíamos chamar de "fator raça" e, no fundo, é um elemento dificultador da evolução: “Assim, quanto maior o papel da hereditariedade na distribuição das tarefas, mais essa distribuição é invariável e, por conseguinte, mais o progresso da divisão do trabalho é difícil, mesmo quando tal progresso seria útil” (Durkheim, 1999, p. 310).

Mais um exemplo dessa divisão de funções decorre do fato de que há uma espécie de organização do trabalho fisiológico: "Mas também as mudanças que se produzem na organização do trabalho fisiológico são muito raras, restritas e lentas" (Durkheim, 1999, p. 311). Mas um dos melhores exemplos da hereditariedade na distribuição do trabalho vem do regime social de castas: "No entanto, assim que aparece de uma maneira caracterizada, a divisão do trabalho se fixa sob uma forma que se transmite hereditariamente: é assim que nascem as castas" (Durkheim, 1999, p. 311). Durkheim dará como exemplo o caso de Hipócrates, o $17^{\circ}$ médico de sua família. Assim, a hereditariedade só empresta-nos conservação e estabilidade. Além disso - mesmo que Durkheim não o diga - ainda podemos pensar na primeira divisão fisiológica do trabalho social: os mais fortes fisicamente seriam guerreiros e os mais inteligentes, os líderes.

Durkheim irá equiparar as castas às classes sociais para afirmar que é necessário a sua superação - pois a classe social leva à individualização. Portanto, a modernidade tenderia, justamente, a diminuir a incidência da hereditariedade (ou anulá-la), na definição profissional. Por isso, o casuísmo e o diletantismo tendem a recuar, como arranjos artificiais.

Na modernidade, a tendência é de que as dinastias profissionais se desfaçam — é fácil perceber que não se transmite a genialidade criadora, nem o dom artístico, bem como não se transmite a forma de se usar a inteligência (se para o bem ou para o mal). O que herdamos, por influência direta, são condições objetivas, favoráveis e estimuladoras ou não. Então, para Durkheim, o que formaria o talento criativo e o raciocínio lógico, que se valeriam da divisão do 
trabalho social? Em certo sentido, há virtudes modernas (virtus): o antes e o hoje, o passado e o moderno ou contemporâneo. A modernidade, realmente, teria trazido novidades:

\begin{abstract}
Numa palavra, a civilização só pode se fixar no organismo pelas bases mais gerais sobre as quais repousa. Quanto mais se eleva acima, mais, por conseguinte, se liberta do corpo; ela se torna cada vez menos uma coisa orgânica, cada vez mais uma coisa social. Mas, então, já não é por intermédio do corpo que ela se pode perpetuar - em outras palavras, a hereditariedade é cada vez mais incapaz de garantir sua continuidade (Durkheim, 1999, p. 329).
\end{abstract}

A divisão do trabalho, então, reafirma-se e deixa a hereditariedade para trás, no curso da história que nos trouxe até à modernidade do século XXI: "O indivíduo fica, pois, menos fortemente preso a seu passado - é-lhe mis fácil adaptar-se às novas circunstâncias que se produzem, e os progressos da divisão do trabalho se tornam, assim, mais cômodos e mais rápidos" (Durkheim, 1999, p. 337). Uma especialização rígida, ao contrário, pode ser sinal de incapacidade de mudar, por isso não determina hierarquia: a mobilidade profissional hoje em dia é indicação clara dessa regra. A civilização, então, terá um papel determinante na demarcação desse processo, pois outra regra de ouro diz que o aumento da produção de excedente desenvolve as sociedades mais dinâmicas (Durkheim, 1999, p. 350). E neste sentido a densidade cultural será explicativa da civilização (e da sociedade capitalista moderna):

\begin{abstract}
O aumento da substancia orgânica é, pois, o fato que domina todo o desenvolvimento zoológico. Não é surpreendente que o desenvolvimento social esteja submetido à mesma lei [...] Portanto, só resta como fator variável o número de indivíduos que se relacionam e sua proximidade material e moral, isto é, o volume e a densidade da sociedade. Quanto mais são numerosos e quanto mais de perto exercem sua ação uns sobre os outros, mais reagem com força e rapidez; mais, por conseguinte, a vida social se torna intensa. Ora, é essa intensificação que constitui a civilização (Durkheim, 1999, p. 351).
\end{abstract}

A sociedade capitalista moderna se desenvolve com a divisão do trabalho social e assim gera uma maior capacidade de gerir seu próprio progresso material e social. Disso ainda resulta que o indivíduo segue estas mudanças mais abrangentes de seu meio social, destas que seriam as forças móveis da civilização: incidência da força do social sobre o individual. Portanto, de lá de trás da história, para os dias atuais, é a sociedade moderna que constitui a própria consciência capitalista. Mas estas forças sociais, morais e materiais de afirmação da modernidade também produzem anomias, como ocorre com as falências (além do exemplo do suicídio):

Um primeiro caso desse gênero nos é fornecido pelas crises industriais ou comerciais, pelas falências que são verdadeiras rupturas parciais da solidariedade orgânica [...] $O$ antagonismo entre o trabalho e o capital é outro exemplo, mais contundente, do mesmo fenômeno. À medida que as funções industriais vão se especializando, a luta se torna mais viva, em vez de a solidariedade aumentar. Na Idade Média, o operário vive em toda parte 
ao lado do patrão, partilhando seus trabalhos "na mesma loja, na mesma bancada" (Durkheim, 1999, pp. 368-369).

Vimos como Durkheim reconheceu o lugar da luta de classes na construção da modernidade, mas Marx diria das crises cíclicas e existenciais do sistema capitalista — portanto, não como situação secundária, mas vital do sistema. De qualquer modo, como Marx, Durkheim perceberá como a aglomeração dos trabalhadores acirrará a luta de classes: "A partir do século $\mathrm{XV}$, as coisas começaram a mudar. A corporação de ofício já não é um asilo comum; é de posse exclusiva dos patrões, que decidem sozinhos todos os assuntos [...] A força da associação dava aos operários o meio de lutar com armas iguais contra seus patrões” (Durkheim, 1999, p. 369).

No século XVII há um acirramento da luta de classes, mas o que explica mesmo o fenômeno é a grande indústria: “Ao mesmo tempo que a especialização se torna maior, as revoltas se tornam mais frequentes [...] É bem sabido que, desde então, a guerra tornou-se mais violenta [...] Ora, a pequena indústria, em que o trabalho é menos dividido, proporciona o espetáculo de uma harmonia relativa entre o patrão e o operário; é somente na grande indústria que essas discórdias se encontram em estado agudo" (Durkheim, 1999, pp. 370-371).

Assim, o cérebro não cria a unidade do organismo, mas a exprime e a coroa [...] Para que a sensação do estado de dependência em que estamos fosse eficaz, seria necessário que também fosse contínua, e só pode sê-lo se estiver ligada ao jogo mesmo de cada função especial [...] a ação governamental terá por objeto manter entre as profissões uma certa uniformidade moral, impedir que "as relações sociais, gradualmente concentradas entre os indivíduos de mesma profissão, se tornem cada vez mais estranhas às outras classes..." (Durkheim, 1999, pp. 376-377).

Desse modo, Durkheim retoma Comte para afirmar o papel do Estado como mecanismo regulador dos conflitos e para impedir que a dispersão das funções tenha um papel desagregador e dissolvente da sociedade. No entanto, o Estado não deve regular a divisão do trabalho social, oriunda das condições estabelecidas pelo mercado - seria como barrar a força motriz da civilização. Portanto, o Estado deve apenas criar um organismo a partir da dependência gerada pelas especializações. A crença maior aqui presente (e que o distancia completamente de Marx) é que Durkheim acreditava na capacidade do Estado de evitar a própria luta de classes, pois a divisão do trabalho movimenta uma força centrífuga, provocando a luta de classes, e deveria ser contida. O caminho, então, além da ação governamental, estaria em reforçar a ação da solidariedade orgânica ou contratual:

Para que a solidariedade orgânica exista, não basta haver um sistema de órgãos necessários uns aos outros e que sintam, de um modo geral, sua solidariedade, mas é necessário, além 
disso, que a maneira como devem concorrer, se não em toda espécie de encontros, pelo menos nas circunstancias mais freqüentes, seja predeterminada (Durkheim, 1999, p. 381).

A solidariedade orgânica, portanto, deve regular a concorrência, admitindo-se que seja forte esta força entre contrários - a solidariedade, de quebra, ainda deveria combate os estados de anomia. Com a força agregadora da solidariedade orgânica, a própria luta de classes seria reduzida a uma mera indisposição pessoal. Com o que também se conclui que a solidariedade decorre dessa harmonia e só poderia ser espontânea. A solidariedade contratual, na modernidade das relações econômicas, deveria resultar em algum tipo de contrato consensual, moral, de valor elevado da "consciência coletiva":

“O contrato consensual só aparece numa época relativamente recente. É um primeiro progresso no sentido da justiça [...] Enfim, a moral comum condena mais severamente ainda qualquer espécie de contrato leonino, em que uma das partes é explorada pela outra, por ser a mais fraca e não receber o justo preço por seu esforço"” (Durkheim, 1999, pp. 404-405).

Para Durkhiem, industrialismo e racionalismo deve inibir as anomias sociais - com essa fórmula o sociólogo francês irá integralizar o Estado Moderno. Neste aspecto, a moderna racionalidade tanto se aplica ao cotidiano quanto à política.

\section{IV - Ressocialização pelo crime}

A questão não é mais simplesmente saber se o sistema penal seria capaz ou não de ressocializar. Evidentemente, é muito mais complexo modificar uma determinada compleição política, uma convicção ideológica, uma crença mística no crime. No mundo contemporâneo, o enfrentamento político - como partidarismo ou definição intransigente de um lado, na luta entre amigo/inimigo substituiu as dificuldades culturais enfrentadas pela ressocialização. De forma simples e direta, o crime se organizou como partido.

A principal questão não é mais a ressocialização, ao menos não tem mais o status, a mesma referência política. Ou, dizendo de outro modo, os significados políticos atribuídos à criminalidade estão em patamar distinto, talvez superior. Antes, era comum uma política criminal; hoje, é fato a política criminosa que alimenta o crime. O crime organizado desenvolveu uma estrutura política própria, especializada aos seus fins. Antes, éramos criados sob o "mito do Estado", em que as

\footnotetext{
${ }^{1}$ Não deixa de expressar a legitimidade alegada por muitos, inclusive por Rousseau.
} 
instituições encarnavam a nação; hoje, cresce o "mito do crime", com seus partidos, rituais, místicas, hinos e comunidades. Neste sentido, além das dificuldades inerentes da ressocialização convencer o indivíduo infrator a "trair sua índole" - agora, está postado o confronto com o mito de que o crime (re)compensa.

Lutar contra a mais que imperfeita realidade fática de um sistema prisional animalesco é uma coisa, mesmo com a evidenciação de que alguns presos criam crostas na pele, como musgo, limbo em que aderem fungos, bactérias, germes, sujeira. É triste demais, horripilante, mas é possível remover tudo isso. Realidade bem diferente é lutar, enfrentar o mito, porque o mito é uma crença cega que reúne em si o real e o surreal. Se o sistema carcerário "dessocializa" o ser social, remove dele qualquer traço de sociabilidade que levava - "institucionalizando-o", obriga-o a seguir as regras inerentes ao sistema -, é em si algo complexo, mas compreensível. De natureza bem diversa é o mito, porque é uma estrutura mental, moral, política à procura da razão instrumental, lucrativa, realista ("o crime tem que dar lucro"), mas com base lastreada na mais pura irracionalidade. Por que saldar a violência, a morte, a corrupção dos corpos e das almas?

\section{V - O crime politizado}

O crime organizado é politizado, partidarizado, tem representação jurídica, institucional. Se o Primeiro Comando da Capital - PCC afronta o Estado é porque cresceu como força política capaz de rivalizar com o poder público, como na demonstração de força que parou o Estado de São Paulo em 2006.Nesta época, aterrorizados com as execuções sumárias, os policiais aplicavam a seguinte lógica quando combatiam nas ruas:

(1) o policial tinha que se precaver;

(2) ele sabia onde estavam os suspeitos;

(3) não havia tempo para investigações;

(4) fogo no suspeito.

Não é difícil perceber que o Estado enfrenta uma força político-criminosa organizada, com recursos, e se vivemos em guerra civil sem que as forças de segurança reconheçam, é porque equivaleria a anunciar a perda da soberania. Nossa Razão de Estado se revela sem capacidade para esse tipo de confronto - a guerrilha urbana do crime leva a vantagem - os policiais são caçados na rua. Para seus membros, seguidores ou apoiadores, o partido é uma alternativa às injustiças do Estado de Direito; aliás, como anuncia seu Estatuto: "Iremos revolucionar o país dentro das prisões 


\section{Quaestio Iuris}

e nosso braço armado será o Terror 'dos Poderosos' opressores e tiranos [...] como instrumento de vingança da sociedade na fabricação de monstros”. Não é uma visão ingênua esta que denuncia a sociedade como fábrica de monstros - é realista, fala com conhecimento próprio.

Se as leis do mercado - "vale tudo pelo lucro", pela expropriação, pelo simples desejo do "ter" - assinalam para os vencedores que estes "não podem ter clemência com a concorrência", então, é fato mais do que lógico e óbvio que o ladrão de propriedades, como um membro qualquer desta sociedade capitalista, não deverá estar imune à ânsia de possuir a propriedade alheia. Um preso refinado, intelectualizado ainda poderia alegar em sua defesa que agiu conforme as leis do mercado - expropriação e apropriação individual, egoísta - e que deveria ser inocentado. Foi o que fez o PCC ao exibir em canal de televisão nacional as suas reivindicações, clamando pelo cumprimento do Estado Democrático de Direito. O que não é irônico e nem contraditório, uma vez que o preso tem perfeita noção prática do que é a dignidade humana.

Em todo caso, muitas estruturas políticas foram copiadas pelo crime organizado, do Estado, como: segurança, controle, racionalidade administrativa ("contabilidade por partida dobrada"), tribunais de julgamento, cartilhas com regras escritas. Contudo, abomina-se a morosidade, a ineficácia e abatem com a morte a corrupção de seus membros agindo contra a associação criminosa. Porém, ironicamente, a estrutura que se alimenta da corrupção do sistema do Estado de Direito não tolera internamente os corruptos. Além de que são julgados por verdadeiros tribunais do crime, com a aplicação de leis muito mais severas do que as do Estado de Direito. Como veremos, isto indica o nascimento de um mito.

\section{VI - Mitologia do crime organizado}

Além de uma narrativa, ainda há mais três sentidos complementares para uma definição inicial de Mito: 1) forma simplificada de intelectualidade; 2) forma autônoma de vida ou de pensamento; 3) instrumento para estudo social (Abbagnano, 2000). O mito não é uma simples narrativa histórica, masuma "representação generalizada de fatos que recorrem com uniformidade na vida dos homens": nascimento e morte; necessidades e forças da natureza; luta e derrota ou vitórias, sexualidade.

O mito não reproduz a realidade; ao contrário, precisa embelezar, corrigir e aperfeiçoar a própria representação. A relação entre o mito e a realidade é dialética (negativa-reconstrutiva). Autores variados preferem a noção de retroalimentação (feedback), porque o mito modifica o universo social originário e esta mudança social acaba por remodelar o mito outra vez, e assim por diante. Assim, o mito não é definido 
só por uma estética ou forma do espírito, como sói acontecer no intelecto ou sentimento. Deste modo, a função social desempenhada pelo mito nas sociedades humanas, é descrita com base em fatos observáveis empiricamente.

Se no passado líamos na escola sobre o mito do "bom mocismo" (do filósofo J.J. Rousseau a Ceci e Peri, de José de Alencar); no presente, milhares de jovens são embalados pelo mito do crime: do baile Funk que toca o "pancadão" (incitando ao crime) ao estilo de vida que recompensa mais do que trabalhar e produzir. Portanto, a mitologia do crime - iniciada no jeitinho brasileiro, na gambiarra das leis - se espraia em toda a sistemática social e, ainda mais, instala-se como partido e representação política. Nesta ideologia do crime - muito mais grave do que a "apologia ao crime" -, para seus seguidores, o que mata é a fome, a polícia, o Estado, não o crack e nem o latrocínio. O traficante substituiu as principais políticas públicas e neste momento coloniza as mentes com seu mito de "sucesso viril”. Não há o bem sem o mal:

Deus e o Diabo se tornam prosaicos, cotidianos, diferentes, irreconhecíveis, outros de si mesmos; substituídos ou personificados pelo dinheiro, consumo, ostentação, cobiça, violência. Tudo se seculariza na trama das relações, processos e estruturas que constituem a vida social e cultural, os trabalhos e os dias de uns e outros; todos [...] Para uns soltou-se do Diabo. Para outros, revelou-se o Diabo no corpo do Homem (Ianni, 1989, p. 209).

O pensador italiano Maquiavel descrevia a relação/ação política baseada na metáfora do Centauro, porque a política se resolveria no misto do consenso, bom senso e racionalidade - como as melhores marcas humanas - e, ao mesmo tempo e ao revés disso, na coerção, força, imposição como se o político agisse com a força de um perverso animal. E o próprio Estado seria resultado direito de uma mitologia sobre a sobrevivência e confiança social, tanto nas teorias do contrato social, quanto no sentido de a dominação política ser o prêmio merecido dos mais fortes. Seriam o aforismo no Mito da Razão de Estado:

O que a razão de Estado da todo-poderosa economia tão cinicamente declara atinge,
inconfessadamente, os modos de conduta dos indivíduos [...] Segundo todos os desiderata
da moral privada, e ainda dos mais avançados, o rico poderia, se quisesse, ser de fato
melhor do que o pobre [...] A bárbara religião atual do êxito não é, pois, somente
contraria à moral; o Ocidente descobre também nela um caminho para regressar aos
honrosos costumes dos pais [...] Toda a moral se configurou sempre pelo modelo do
imoral $[. .$.$] A moral dos escravos é, de fato, má: é ainda sempre a moral dos senhores$
(Adorno, 2001, p.191 - grifos nossos).

Para Cassirer, o mito é a própria força que move o pensamento: "De todas as coisas do mundo, o mito parece ser a mais incoerente e inconsciente" (Cassirer, 2003, p. 57 - grifos nossos). Mas, o é tão-só no sentido de que pertence mais aos sentimentos do que à razão destinada ao fim determinado - no MITO DO ESTADO, embora esteja recheada de retórica e 
de exercícios lógicos de convencimento, o que move a paixão do povo é o instinto de sobrevivência, pois que ainda se encontram totalmente imersos na luta pela auto-conservação.

É o inconsciente que moverá as ações e tornará as expectativas passíveis de objetivação - estranhamente, paradoxalmente, é como se o inconsciente-incoerente, viesse a se tornar a fonte da razão necessária a toda forma significativa de objetivação pessoal e social. É como se o significado razoável a CRENÇA COMUNITÁRIA brotasse da própria ausência de outro sentido mais claro expresso - só o que se sabe é que é necessário fazer.

Essa subjetividade mais íntima é a fonte da objetivação intersubjetiva (pois, trata-se de sonho coletivo exteriorizado): “O mito não pode ser descrito como uma simples emoção porque é a expressão de uma emoção. A expressão de um sentimento não é o próprio sentimento — é a emoção tornada imagem" (Cassirer, 2003, pp. 63-64 - grifos nossos). Trata-se do mito do pertencimento ao comunitarismo e também promove uma objetivação de sentidos e de sentimentos. Em se tratando do Mito da Razão de Estado, o destino é ter uma sociedade superior e um Estado-guia que nos traga o Bem Supremo, sempre destinado aos melhores e aos mais fortes. Por isso, se os aparatos do Poder são direcionados aos escolhidos, então, esses é que definem o que é e os porquês.

Quando advém a consciência, acima da razão (embora não sem esta), além de um quê (Razão de Estado), passa a importar o porquê (não só o Estado, mas além dele o Estado Forte). Por exemplo, já não basta apenas viver, é preciso um modo de vida em que as raízes do mito (embora já decodificadas pela razão instrumental) sejam possíveis de um compartilhamento intersubjetivo. E esta é justamente a garantia dada pela exceção: tudo em nome de um tempo melhor! O mito, em si, já é uma resposta às mais ásperas angústias: De onde viemos? Para onde vamos? Mas, ainda mais curiosamente, também será uma resposta aos porquês formulados: será que pegamos o caminho correto?

O mito é a resposta que congrega a (re)pergunta, a tese que leva diretamente à síntese, pode ser tido como a fonte da razão: a motivação que nos faz (re)pensar nos sentidos; é outra busca de sentidos, motivada por perguntas simples de se fazer, mas complexas para se responder; impreterivelmente é um ato de razão, por ser intencional. Por mais paradoxal, pode-se ver como o mito desencadeou todo o processo de desencantamento: "Tão depressa um homem começa a refletir acerca dos seus atos, deu um passo decisivo; penetrou num caminho novo, que no fim o conduzirá longe da sua vida inconsciente e instintiva" (Cassirer, 2003, p. 67). 
Esse ascetismo impulsionador do mito da Razão de Estado, portanto, é também um desapego do mundo, mas não de encontro ao nirvana. Isto porque, simplesmente, do desencantamento se originou um mundo cada vez mais esquemático. Então, o desencantamento que consta das causas do mito primal da Razão de Estado é mais um desapego do mundo natural (em prol do mundo político), dos sentidos e das razões naturais, em troca de atos passados e pensados, são como atos políticos originários. Esse mito primal da Razão de Estado marcou a passagem do Homo naturalis ao Homo sociologicus, tanto quanto aí se instalou uma tensão entre o privatus e o comus: entre o público e o privado. Por isso, podemos dizer que a tese soberana da Razão de Estado é o poder a todo custo - e o é, certamente, lógico, pois, sem esse anátema não há soberania.

Com a soberania sistematizando, positivando, "legitimando" o mito de origem do Estado, anátema da violência natural e sua superação pela razão pública, surgiu tempos depois outro mito: Estado de Direito. Não apenas a justiça estava colocada, mas antes disso o próprio mito da neutralidade do Poder Judiciário. E um mito mais fulgurante, ainda mais presunçoso, utópico, de que o Judiciário e seu conjunto de leis seria capaz de contornar, controlar o Estado, ou seja, de que o direito seria capaz de se impor ao poder - e não o inverso, como demonstra a realidade política.

Nesta linha do realismo político, desprovido do mito da supremacia do direito, a mitologia do crime revelou-se com base em dados históricos e concretos. Assim, um homicídio (1993) é considerado o marco simbólico da criação do PCC. Transformado em narrativa mítica, a imagem da irmandade constituída de experiências comuns de sofrimento e de opressão entre os "irmãos”, é reatualizada no batismo dos ingressantes, quando ainda se tem a leitura do estatuto e a relembrança dos abusos cometidos pelas autoridades.

A realidade do poder que se impõe pelo partido a seus membros, entretanto, não tem nada de mística. O PCC financia as visitas de familiares dos presos e depois lhes cobra a conta. Fato que talvez explique o alto índice de reincidência dos condenados, pois eles saem da cadeia endividados e precisam voltar ao crime para pagar a conta. Com todos os presídios dominados pelo PCC ou por seus rivais, temos a privatização do sistema carcerário de São Paulo. O PCC controla a rotina dos presídios, os conflitos são resolvidos pela "mediação e disciplina".

Adeptos do PCC misturam a reza católica com o hino de apologia ao crime. Sua mitologia produziu hinos como: “Ao poder! Amém...Um por todos! Todos por um”. O triunfalismo está presente neste sincretismo de realismo político e ufanismo religioso - neste tipo de "destino 
manifesto", seus líderes são consagrados como heróis (se bem que alguns podem ser eliminados se falham nas estratégias, como após a rebelião de 2006).

\section{VII - Dividir para conquistar}

Uma das maiores verdades da política ensina a "dividir para conquistar". No Estado de São Paulo, permitiu-se que um grupo ou associação criminosa elimina-se sua concorrência e se fortalecesse como cartel ou monopólio do crime. Antes disso, em 1987, foram mortos centenas no presídio Carandiru; em 1990, a Lei dos Crimes Hediondos soterraria a ressocialização e a polícia mataria demais nas ruas paulistanas. Além disso, conclui-se que o Estado fomentou a criação de um "pensamento único" do crime.

Depois, novos grupos ramificaram-se: Comando Democrático pela Liberdade (1996); Comando Revolucionário Brasileiro da Criminalidade (1999) - seus membros são conhecidos como "coisas". Será uma coincidência? Como verdadeira dissidência ideológica, o Terceiro Comando da Capital defende o fim da cobrança de mensalidade dos "filiados", da extorsão de familiares e da violência contra os próprios integrantes. Grupos menores são a Seita Satânica e a Sociedade Anônima. Ocorre que, se somados, esses grupos não chegam a $5 \%$ da população carcerária. Logo, o Estado criou um monopólio.

No Rio de Janeiro, a relação é ainda mais estreita, pois as milícias são formadas por policiais, bombeiros, oficiais, militares treinados e expulsos pelo Estado. Lembrando-se que muitos dos militares formados em forças especiais, em comandos, atingiram o limite de idade e foram dispensados pelas forças armadas. Para onde teriam ido, se foram treinados a vida toda para dissimular, ocupar, matar?

Todos os grupos têm estatuto próprio, escriturando as regras como direito positivo, efeito erga omnes, coerção no império da sua lei. Há profissionalização das funções: disciplina, gerência, inteligência. Antes centralizado, o PCC reinventou sua estrutura política; descentralizado, dividese em células, as chamadas "sintonias". Há muitas: uma Sintonia do Interior, a sintonia da ajuda (fornece dinheiro para presos e parentes), do prazo (relaciona os devedores), "bicho-papão" (cria sorteios e dá prêmios), da rua (coordena os "irmãos livres”), dos salves (divulgação das ordens da cúpula), do livro (cadastra os que entram na facção) e "dos gravatas" (advogados).

Primeiro vimos surgir a liturgia e a estética do crime - como no cangaço - e agora temos sua mitologia. O maior problema político eivado do partido, na mitologia do crime, é que sua 
mística não é nada parecida com a de Robin Hood. Também por isso o crime organizado é muito mais de ordem política, do que mera questão policial.

\section{VIII - Uma última ponderação}

Como vimos, a amizade, liame social, maior ou menor é determinada pela divisão do trabalho. O casamento é outra instituição fundamental da sociedade moderna e será marcada pela própria divisão social (sexual) do trabalho. Porém, no plano geral, a divisão do trabalho é a fonte de toda solidariedade, quando os opostos se atraem e se complementam. Para Durkheim, Comte foi o primeiro a defender a tese civilizatória da divisão do trabalho. À base de uma "físiologia social", ambos viam a divisão do trabalho como o sustento de todo o organismo social.

O que equivale a dizer, novamente, que a divisão do trabalho está associada à vida moral. Daí que deveria originar um direito que organizasse a vida social - o mesmo direito que deverá, decerto, regular a própria divisão do trabalho. Em suma, a solidariedade (gerada pela divisão do trabalho) é um fato social e Durkheim fará uso do direito para melhor compreendê-la (Durkheim, 1999, pp, 30-32).

Todavia, é preciso entender que mesmo para os clássicos a aprendizagem e a sociabilidade tem curso durante toda a vida, ainda que haja uma fase, idade mais marcante, visível em termos de influência na personalidade moral, na cognição. A socialização é um processo de toda a vida, portanto, não um momento que se esgota na formação inicial. O que ainda permite dizer que a expressão socialização primária não está de todo modo correta, uma vez que, como processo, não há um setor primário e outro secundário, há um processo, um fluxo contínuo e ainda que variado em termos de aprendizagem e de socialização (que é a aprendizagem das normas abstratas).

Na presença de um mínimo de entropia social observamos um eterno recomeço, quando novamente o homem dá início à procura de transformar o meio em cultura, agindo através do trabalho social.

Por que existe a entropia? Antes, muitas vezes se admitia que a entropia não era senão a expressão de uma fenomenologia, de aproximações suplementares que introduzimos nas leis da dinâmica. Hoje sabemos que a lei de desenvolvimento da entropia e a física do nãoequilíbrio nos ensinam algo de fundamental acerca da estrutura do universo: a irreversibilidade torna-se um elemento essencial para a nossa descrição do universo, portanto devemos encontrar a sua expressão nas leis fundamentais da dinâmica [...] De qualquer forma [...] é do caos que surgem ao mesmo tempo ordem e desordem (Prigogine, 2002, pp. 79-80). 
Enfim, cultura é a capacidade humana de responder organizadamente às necessidades e assim transformar a natureza coletivamente, trabalhando e fabricando a inteligência social.

\section{IX - Referências}

ABBAGNANO, Nicola. Dicionário de Filosofia. 4ª ed. São Paulo: Martins Fontes, 2000.

ADORNO, TH. W. Minima Moralia. Lisboa-Portugal : Edições 70, 2001.

CASSIRER, Ernst. O mito do Estado. São Paulo: Códex, 2003.

DURKHEIM, Émile. Lições de sociologia: a Moral, o Direito e o Estado. São Paulo: T. A. Queiroz:

Ed. da Universidade de São Paulo, 1983.

Sociologia, Educação e Moral. Porto-Portugal: Rés, 1984.

Sociologia. $4^{\text {a }}$ ed. São Paulo: Ática, 1988.

Socialismo. Rio de Janeiro: Relume-Dumará, 1993.

Da divisão do trabalho social. $2^{\text {a }}$ ed. São Paulo: Martins Fontes, 1999.

As regras do método sociológico. $2^{\text {a }}$ ed. São Paulo: Martins Fontes, $1999 \mathrm{~b}$.

Ética e sociologia da moral. São Paulo: Landy, 2003.

A educação como processo socializador: função homogeneizadora e função diferenciadora. IN

:Foracchi, Marialice M. (org). Educação e Sociedade. São Paulo: Companhia Editora Nacional, 1979.

IANNI, Octavio. Sociologia da Sociologia. $3^{\text {a }}$ ed. São Paulo: Ática, 1989.

MARTINEZ, Vinício Carrilho. Educação, Política e Tecnologia na Formação do Cidadão. Dissertação de Mestrado em Educação. UNESP - Faculdade de Filosofia e Ciências: Marília- SP, 1993-1996.

O cidadão de silício. UNESP - Faculdade de Filosofia e Ciências: Marília- SP, 1997.

A rede dos cidadãos: a política na Internet. Tese de doutorado em Educação. São Paulo : Faculdade de Educação da Universidade de São Paulo (FEUSP), 2001.

Estado de (não)Direito: quando há negação da Justiça Social, da Democracia Popular, dos Direitos Humanos. Mestrado em Ciências Jurídicas. Paraná: Universidade Estadual do Paraná UNESPAR. Faculdade Estadual de Direito do Norte Pioneiro - FUNDINOPI, 2005.

O direito à educação no Estado Cientificista - a contribuição dos clássicos das ciências sociais na delimitação da modernidade. Pesquisa de Pós-Doutorado em Ciências Sociais.

UNESP/Marília, SP: [s.n.], 2009. 
Estado de Exceção e Modernidade Tardia: da dominação racional à legitimidade (anti) democrática. Tese de Doutorado em Ciências Sociais. UNESP/Marília, SP: [s.n.], 2010.

Os Códigos da Prudência. Pesquisa de Pós-Doutorado em Ciências Sociais. UNESP/Marília, SP: [s.n.], 2011.

MORA, J. Ferrater. Dicionário de Filosofia. Tomos I, II, III, IV. São Paulo: Loyola, 2001.

PRIGOGINE, Ilya. As leis do caos. São Paulo: Editora da UNESP, 2002.

SANTOS, Fátima Ferreira P. dos @ MARTINEZ, V. C. Estado penal: a miséria e a venda do Estado de Direito. Perspectivas: Revista de Ciências Sociais (UNESP. Araraquara. Impresso), v. 36, p. 209-235, 2009. 